ISSN 1818-1295 elSSN 2616-6194

REPORTS OF MORPHOLOGY
$\begin{gathered}\text { Official Journal of the Scientific Society of Anatomists, } \\ \text { Histologists, Embryologists and Topographic Anatomists } \\ \text { of Ukraine } \\ \text { journal homepage: https://morphology-journal.com }\end{gathered}$

\title{
Morphometric peculiarities of the cervix uteri in immunodeficiency states
}

Lytvynenko M.V. ${ }^{1}$, Gargin V.V. ${ }^{2}$

${ }^{1}$ Odessa National Medical University, Odessa, Ukraine

${ }^{2}$ Kharkiv National Medical University, Kharkiv, Ukraine

\author{
ARTICLE INFO \\ Received: 22 July, 2020 \\ Accepted: 25 August, 2020 \\ UDC: $616-018: 618.11-007.21: 616-$ \\ 091.817:616.9
}

\section{CORRESPONDING AUTHOR}

e-mail: lytvynenko_marianna@ukr.net Lytvynenko M.V.

\begin{abstract}
Enhancing each other's effects - HIV infection and the changes caused by alcohol abuse, trigger a chain of pathological reactions that sometimes lead to reversible and often irreversible pathological processes in the cervix uteri (CU). Local and general decrease in immunoresistance invariably leads to disturbance of physiological CU microbiome. Given all the above, the aim of our work was to identify pathological changes in CU that occur in HIV-infected women on the background of chronic alcoholism. Section material of 110 women of reproductive age from 20 to 40 years, which were divided into four groups, was studied. After the manufacture of micropreparations, a morphometric study was performed. Significant pathological changes in CU were revealed in HIVinfected women suffering from alcoholism. The maximum thickness of nonkeratinized stratified squamous epithelium $\left(734.23 \pm 61.33 \times 10^{-6} \mathrm{~m}\right)$ was characteristic of a group of HIV-infected women suffering from chronic alcoholism. In HIV-infected women, this figure is $3.14 \%$ lower and is $711.21 \pm 59.28 \times 10^{-6} \mathrm{~m}$. In women suffering from alcoholism without concomitant HIV infection, this figure is $697.8 \pm 47.88 \times 10^{-6} \mathrm{~m}$, which is $5 \%$ less than in the group with combined pathology. As expected, the lowest value was in the comparison group, where it was $527.23 \pm 44.37 \times 10^{-6} \mathrm{~m}$. There was a significant difference between the comparison group of HIV-infected women with alcoholism and the control group, which is $28.2 \%$. In the studied material of HIV-infected patients, a high degree of distribution of the severity of cervical dysplasia was determined - $9.1 \%$. Moderate and low degree, respectively, 19.42 and $37.12 \%$ in this group of subjects. When studying the degree of infiltration of the lamina propria mucosa in the study groups, it was found that the largest number of cases of severe infiltration (44.5\%) was found in the group suffering from chronic alcoholism, and in the HIV groups no such case was detected. On the basis of the conducted research it is possible to assume the combined influence of the factors promoting development of pathological processes both in an epithelium, and in a mucous membrane of CU. Thus, HIV infection and alcohol abuse can exacerbate each other's pathological effects and lead to pronounced pathomorphological changes in $C U$, namely: thickening of the mucosal epithelium due to frequent development of various types of warts, mucosal dysplasia and even severe cellular infiltration of the mucous membrane.

Key words: cervix uteri, HIV, alcoholism, epithelium, histology.
\end{abstract}

\section{Introduction}

Diseases of the cervix uteri $(\mathrm{CU})$ are widespread in the population, which is associated with low detection rate, imperfection of the medical system, sometimes with asymptomatic or poor symptoms of inflammatory and noninflammatory processes in this area $[3,8]$.

Although periodic medical examinations and regular cytological screenings are designed to reduce morbidity and mortality rates among women, the problem of $\mathrm{CU}$ pathological processes is extremely acute today [7]. The prevalence of this group of diseases remains high both in Ukraine and throughout the world [19].

Special attention of medical personnel in terms of the complexity of the clinical course, diagnostic features, individual approach to treatment is occupied by risk groups [12]. The greatest variability and complexity of the course of this group of diseases differs in women with immunosuppression [20, 22]. At the same time, HIV-infected women and women suffering from alcoholism represent a 
global problem [16, 18].

Strengthening the effects of each other, both HIV infection and changes caused by alcohol abuse trigger a chain of pathological reactions leading to reversible and often irreversible pathological processes in CU [13, 17].

As it is known, ethanol, which is the main component of all alcoholic beverages, belongs to the 1st category of carcinogens, which means that there are reliable signs of its carcinogenicity for humans.

On the other hand, a local and general decrease in immunoresistance invariably leads to a disruption of the physiological microbiome of $\mathrm{CU}$, which means that it increases the risk of infection with pathogenic microorganisms, fungal flora, viruses, in particular, the human papillomavirus (HPV) [6, 9]. 99\% of all precancerous diseases occur against the background of HPV infection [1, 4]. To date, there are many studies devoted to changes in $\mathrm{CU}$ due to alcoholism, as well as in HIV infection, however, there are no data on changes in $\mathrm{CU}$ when these pathological processes are combined, which is very important, since they are very often combined in this cohort of patients.

Considering all of the above, the purpose of our work was to identify pathological changes in the cervix that occur in HIV-infected women against the background of chronic alcoholism.

\section{Materials and methods}

For the study, we took material from 110 women of reproductive age from 20 to 40 years. All the subjects were divided into 4 groups. Group 1 (30 women) consisted of women diagnosed with HIV infection. In this group, both the anamnestic data (interviewing relatives) and the autopsy results (the main symptom was the presence of alcoholic cirrhosis of the liver), alcohol abuse was confirmed. The second group (25 women) consisted of people with confirmed HIV infection without any data on concomitant alcoholism. In patients of the third group, only anamnestic and postmortem signs of alcohol abuse were identified. The control group consisted of women (30) who died from diseases not related to alcohol abuse, pathology of the reproductive system without concomitant HIV infection (deaths as a result of accidents).

The collected material was fixed in $10 \%$ neutral buffered formalin and then embedded in paraffin. At the next stage, sections with a thickness of $5 \times 10^{-6} \mathrm{~m}$ were made from the prepared paraffin blocks. Subsequently, the sections were stained with hematoxylin and eosin. Microscopic examination was carried out on an "Olympus BX41" microscope with further morphometric examination in the "Olympus DP-soft 3.12" software.

The following indicators were determined: the thickness of the nonkeratinized stratified squamous epithelium (NSSE) in all groups of patients, the relative volumes of warts, expressed as a percentage [5], the distribution of the severity of CIN in the test material as a percentage among the entire test material. Statistical processing of the obtained results was performed using methods of variation statistics. Correspondence of the distribution to the normal distribution was determined by the ShapiroWilk's test, which showed that the samples are close to the normal distribution. Statistical indicators are presented in the format $M \pm \sigma$, where $M$ is the arithmetic mean, $\sigma$ is the standard deviation, Student's t-test. Correlation analysis was carried out using Spearman's rank correlation coefficient. The statistical difference between the studied parameters was considered significant at $p<0.05$.

All studies were conducted in accordance with the Declaration of Helsinki, approved by the Ethics Commission of the Odessa National Medical University (Protocol 3, dated October 17, 2011).

\section{Results}

As a result of the studies carried out, we obtained results, indicating the severity of pathological processes in the $\mathrm{CU}$ in HIV-infected women suffering from alcoholism.

At the first stage, the thickness of the epithelial layer of the cervical mucosa was determined. Table 1 shows the numerical values obtained when determining the thickness of the epithelial layer. The maximum thickness of the NSSE was typical for the group of HIV-infected women suffering from chronic alcoholism - 734.23 $\pm 61.33 \times 10^{-6} \mathrm{~m}$. In HIVinfected women, this indicator is $3.14 \%$ less and is $711.21 \pm 59.28 \times 10^{-6} \mathrm{~m}$. In the group of examined women who suffered from chronic alcoholism without concomitant HIV infection, this indicator was $697.8 \pm 47.88 \times 10^{-6} \mathrm{~m}$, which is $5 \%$ less than in the group with combined pathology. The expected minimum indicator was in the comparison group,

Table 1. The thickness of the cervical epithelium in the examined groups of women $(\mathrm{M} \pm \sigma)$.

\begin{tabular}{|l|c|c|c|c|}
\hline \multirow{2}{*}{$\begin{array}{c}\text { Morphological } \\
\text { sign }\end{array}$} & \multicolumn{4}{|c|}{ Study groups } \\
\cline { 2 - 5 } & $\begin{array}{c}\text { HIV } \\
\text { infection }\end{array}$ & $\begin{array}{c}\text { chronic } \\
\text { alcoholism }\end{array}$ & $\begin{array}{c}\text { chronic } \\
\text { alcoholism } \\
\text { and HN } \\
\text { infection }\end{array}$ & $\begin{array}{c}\text { comparison } \\
\text { group }\end{array}$ \\
\hline $\begin{array}{l}\text { Thickness of } \\
\text { nonkeratinized } \\
\text { stratified } \\
\text { squamous } \\
\text { epithelium, } 10^{-6} \mathrm{~m}\end{array}$ & $711.2 \pm 59.3^{*}$ & $697.8 \pm 47.9^{*}$ & $734.2 \pm 61.3^{*}$ & $527.2 \pm 44.4$ \\
\hline
\end{tabular}

Notes: ${ }^{*}$ - the likelihood of differences between comparison groups $p<0.05$.

Table 2. Relative volumes of warts in the surveyed groups of women (\%).

\begin{tabular}{|l|c|c|c|c|}
\hline \multirow{2}{*}{$\begin{array}{c}\text { Types of } \\
\text { genital warts }\end{array}$} & $\begin{array}{c}\text { HIV infectio } \\
(\mathrm{n}=25)\end{array}$ & $\begin{array}{c}\text { chronic } \\
\text { alcoholism } \\
(\mathrm{n}=25)\end{array}$ & $\begin{array}{c}\text { chronic } \\
\text { alcoholism } \\
\text { and HIV } \\
\text { infection } \\
(\mathrm{n}=30)\end{array}$ & $\begin{array}{c}\text { comparison } \\
\text { group } \\
(\mathrm{n}=30)\end{array}$ \\
\hline Genital wart & $16.00(4)$ & $8.00(2)$ & $16.67(5)$ & $3.33(1)$ \\
\hline Flat wart & $12.00(3)$ & $8.00(2)$ & $26.67(8)$ & $3.33(1)$ \\
\hline Plantar wart & $8.00(2)$ & $4.00(1)$ & $10.00(3)$ & $3.33(1)$ \\
\hline Total & $36.00(9)$ & $20.00(5)$ & $53.33(16)$ & $10.00(3)$ \\
\hline
\end{tabular}


Table 3. Severity of cervical dysplasia in the studied groups of women (\%).

\begin{tabular}{|l|c|c|c|c|}
\hline \multirow{2}{*}{} & \multicolumn{4}{|c|}{ Study groups } \\
\cline { 2 - 5 } & $\begin{array}{c}\text { HIV } \\
\text { infection }\end{array}$ & $\begin{array}{c}\text { chronic } \\
\text { alcoholism }\end{array}$ & $\begin{array}{c}\text { chronic } \\
\text { alcoholism } \\
\text { and HIV } \\
\text { infection }\end{array}$ & $\begin{array}{c}\text { comparison } \\
\text { group }\end{array}$ \\
\hline Low degree & $23.32^{*}$ & $15.43^{*}$ & $37.12^{*}$ & 6.92 \\
\hline Moderate degree & $14.21^{*}$ & 8.67 & $19.42^{*}$ & 5.99 \\
\hline High degree & $8.31^{*}$ & 4.61 & $9.10^{*}$ & 3.23 \\
\hline
\end{tabular}

Notes: * - the likelihood of differences between comparison groups $\mathrm{p}<0.05$.

Table 4. The degree of infiltration of the lamina propria by immunocompetent cells in the examined groups of women.

\begin{tabular}{|l|c|c|c|c|}
\hline \multirow{2}{*}{ Infiltration rate } & \multicolumn{4}{|c|}{ Study groups } \\
\cline { 2 - 5 } & $\begin{array}{c}\text { HIV } \\
\text { infection }\end{array}$ & $\begin{array}{c}\text { chronic } \\
\text { alcoholism }\end{array}$ & $\begin{array}{c}\text { chronic } \\
\text { alcoholism } \\
\text { and HIV } \\
\text { infection }\end{array}$ & $\begin{array}{c}\text { comparison } \\
\text { group }\end{array}$ \\
\hline Absence & 4.7 & 0 & 10.3 & 0 \\
\hline Weak & 60.2 & 12.9 & 65.6 & 87.5 \\
\hline Moderate & 35.1 & 42.6 & 34.1 & 9.1 \\
\hline Expressed & 0 & 44.5 & 0 & 3.4 \\
\hline Total & 100 & 100 & 100 & 100 \\
\hline
\end{tabular}

where it was $527.23 \pm 44.37 \times 10^{-6} \mathrm{~m}$. There was a significant difference between the comparison group of HIV-infected women suffering from alcoholism and the control group, which is $28.2 \%$.

One of the possible reasons for changes in the thickness of the epithelium may be a much more frequent development of condylomatous vegetations in the studied groups, especially often associated with HIV infection. During the histological examination of the cervix, three forms of condylomatous vegetations were morphologically verified: genital, flat and plantar. The relative volumes of distribution of such forms are presented in table 2 .

In the group of women surveyed with a combination of HIV infection and alcoholism (see Table 2), attention is drawn to the presence of a greater number of different types of warts: genital warts in this group amounted to $16.67 \%$, flat $-26.67 \%$, plantar $-10 \%$, which in total amounted to $53.33 \%$.

In the group of women with only confirmed HIV infection, similar indicators were 16,12 and $8 \%$, which amounted to $36 \%$.

It should be noted that in the group of women who abused alcohol, there was also an increase in the relative volume of warts among all selected cases. These figures were $8 \%, 8 \%$ and $4 \%$ (only $20 \%$ ) for genital warts, flat and plantar warts, respectively.

Predictably the best results of the studied indicator can confirm the minimum thickness of the NSSE in the control group of women. The relative volumes of warts were $3.33 \%$ for each type of warts, which in total amounted to only $10 \%$.

Another possible change in the thickness of the epithelium is the significantly more frequent cases of CIN. So, in most cases of the comparison group, no signs of dysplasia of the cervical epithelium were detected, while in the studied groups a significant increase in the specific volume of cases with dysplastic changes was revealed. Mild dysplasia is characterized by preserved anisomorphism and stratification of the surface and intermediate layers, focal basal cell hyperactivity with an increase in the nuclear-cytoplasmic ratio. At the same time, the structuring of the nucleoli in the nuclei of the cells of the basal and parabasal layers, their moderate basophilia are revealed.

Depending on the severity of dysplasia, the examined cervix was characterized by normal, weak, moderate or severely disturbed cytoarchitectonics. The nuclei were of normal size or slightly enlarged, had the same oval shape, with predominantly normal polarization and mild hyperchromicity. Mitotic figures were present in $85 \%$ of cases in all layers, in $10 \%$ they were observed only in the basal layer, in $5 \%$ they were few in both the basal and other layers of the epithelium.

With high CIN, a pronounced violation of cytoarchitectonics was observed (the size and shape of the cells varied significantly). Cells with transparent cytoplasm, as a rule, were absent, or there was a small number of them in certain areas, the size of the nuclei varied markedly with a predominance in the direction of increase, the nuclei had different shapes, polarization in many was absent, there was a pronounced hyperchromicity of the nuclei with the presence of even single pathological mitoses and mitotic figures.

The distribution of the test material depending on the severity of $\mathrm{CIN}$ is presented in Table 3 . A high degree of distribution of the severity of CIN was determined in the test material of HIV-infected patients, it was $9.1 \%$. Moderate and low degree, respectively, 19.42 and $37.12 \%$ in this group of persons. The best result according to this indicator was determined in the comparison group. It was 3.23, 5.99 and $6.92 \%$, respectively, for high, moderate and low degrees. The group of HIV-infected women without signs of chronic alcoholism and the group of women with alcoholism occupy an intermediate position, according to the indicators between the two previous groups. The values that were revealed in these studied groups of women were $23.32,14.21,8.31 \%$, respectively.

When assessing the degree of infiltration of the lamina propria by immunocompetent cells (lymphohistiocytes) using the semi-quantitative method from 0 to 3 points $(0-$ absence, 1 - weak, 2 - moderate, 3 - severe infiltration), it was found that the largest number of cases with weak infiltration belonged to the group of combined chronic alcoholism and HIV infection (65.64\%). It should be noted that $10.32 \%$ of cases with no infiltration were found in this group, i.e. almost complete absence of lymphocytes.

When studying the degree of infiltration of the lamina propria in the study groups, attention is drawn to the fact 
that the largest number of cases of severe infiltration $(44.5 \%)$ was found in the group with chronic alcoholism, and not a single such case was found in the groups with HIV.

\section{Discussion}

On the basis of the study, we can assume the combined influence of factors contributing to the development of pathological processes both in the epithelium and in the mucous membrane of CU [1]. On the one hand, this is due to the presence of hormonal imbalance, which can be explained by the presence of sclerotic-degenerative changes in the ovaries [7], which is manifested by a progressive decrease in the size of primordial follicles and a decrease in the number of both primary and secondary, and tertiary follicles due to the presence of HIV infection [13] and concomitant chronic alcoholism [2, 14].

An equally important link in the pathogenetic chain of changes is the effects caused by the influence of confirmed HIV infection [11]. It can be assumed that the main link leading to the development of pathological processes of $\mathrm{CU}$ in this case is pronounced immunosuppression, which leads to an increased risk of HPV infection, the development of various types of genital warts, and the development of dysplastic changes in $\mathrm{CU}[6,18]$. These changes, in turn, are the substrate for the thickening of the mucous membrane, which was the maximum thickness in HIVinfected women suffering from chronic alcoholism [14, 15]. It should also be noted that the thickness index was significantly less $(p<0.05)$ in women who had clinical and anamnestic data only on the presence of chronic alcoholism, compared with the group of HIV-infected women. Therefore, it can be assumed that the presence of HIV infection is of greater importance for the emergence of a cascade of pathological reactions leading to changes in the mucous membrane of the CU $[19,21]$. This assumption could be confirmed by the data obtained in the study of the prevalence of various types of warts and data on the severity of dysplasia [3].

Thus, in the comparison group, the relative volumes of warts were minimal and equally distributed across all three types (genital, flat and plantar). In the group of HIV-infected patients, genital warts prevailed, with a combination of HIV infection and alcoholism - flat, with alcoholism - genital

\section{List of references}

[1] al-Nafussi, A., Rebello, G., al-Yusif, R., \& McGoogan, E. (2000). The borderline cervical smear: colposcopic and biopsy outcome. Journal of Clinical Pathology, 53(6), 439-444. https:/ /doi.org/10.1136/jcp.53.6.439

[2] Bull, L., Tittle, V., Rashid, T., \& Nwokolo, N. (2018). HIV and the menopause: A review. Post Reproductive Health, 24(1), 1925. https://doi.org/10.1177/2053369117748794

[3] Ebisch, R. M., Rovers, M. M., Bosgraaf, R. P., van der PluijmSchouten, H. W., Melchers, W. J., van den Akker, P. A. Massuger, L. F., \& Bekkers, R. L. (2016). Evidence supporting see-and-treat management of cervical intraepithelial neoplasia: a systematic review and meta-analysis. BJOG: an and flat. As is known, the presence of warts many times increases the risks of developing $\mathrm{CU}$ oncological processes [15]. Thus, having only anamnestic data on alcohol abuse, information about a woman's HIV status, data from a physical examination by a gynecologist, the presence of contributing factors for the development of malignant neoplasms can be suspected, which should cause even greater oncological alertness when working with this cohort of persons [16, 22].

In all four groups of patients, the degree of immunocompetent cell infiltration of the lamina propria was determined. It was revealed that the most pronounced infiltration was determined in women suffering from chronic alcoholism. At the same time, in the control group, as in the group of HIV-infected women and even in the group of HIVinfected against the background of chronic alcoholism, weak infiltration prevailed. These changes can be explained by the pronounced immunosuppression caused by HIV infection. Due to this, inflammatory changes do not develop. Consequently, the patients of these study groups are characterized by more dysplastic rather than inflammatory processes in the $\mathrm{CU}$.

Given the prevalence of severe and moderate infiltration of the lamina propria in patients with alcohol abuse, it is in them that a pronounced picture of cervicitis should be expected.

Thus, the data obtained in this study will help to timely and effectively examine women with risk factors in terms of development pathological processes of $\mathrm{CU}$, which means choosing a treatment for correcting these processes, and therefore increasing the duration and quality of life of HIVinfected patients with clinical and anamnestic data characteristic of the presence of concomitant chronic alcohol abuse.

\section{Conclusions}

HIV infection and alcohol abuse can increase the pathological effects of each other and lead to pronounced pathomorphological changes in $\mathrm{CU}$, which consist in thickening of the epithelium of the mucous membrane due to the frequent development of various types of warts, dysplasia of the mucous membrane and also pronounced cellular infiltration of the lamina propria.

International Journal of Obstetrics and Gynaecology, 123(1), 59-66. https://doi.org/10.1111/1471-0528.13530

[4] Edelman, E. J., Williams, E. C., \& Marshall, B. (2018). Addressing unhealthy alcohol use among people living with HIV: recent advances and research directions. Current Opinion in Infectious Diseases, 31(1), 1-7. https://doi.org/10.1097/ QCO.0000000000000422

[5] Gargin, V., Radutny, R., Titova, G., Bibik, D., Kirichenko, A., \& Bazhenov, O. (2020). Application of the computer vision system for evaluation of pathomorphological images. 40th International Conference on Electronics and Nanotechnology (ELNANO), Kiyv. 
[6] Grint, D., Peters, L., Rockstroh, J., Rakmanova, A., Trofimova, T., Lacombe, K. ... Mocroft, A. (2015). Liver-related death among HIV/hepatitis $\mathrm{C}$ virus-co-infected individuals. AIDS, 29(10), 1205-1215.

[7] Kayrin, L., \& Nakonechna, A. (2019). Menstrual cycle-related changes in blood serum testosterone and estradiol levels and their ratio stability in young healthy females. Inter Colleges, (6), 155-161.

[8] Kendall, W. Y., Ho, D., Chu, K., Zinaman, M., Wieland, D., Moragne, K., \& Wax, A. (2020). Prospective detection of cervical dysplasia with scanning angle-resolved low coherence interferometry. Biomedical Optics Express, 11(9), 5197-5211. https://doi.org/10.1364/BOE.401000

[9] Kozko, V. M., Bondarenko, A. V., Gavrylov, A. V., Shevchenko, O. S., \& Gargin, V. V. (2017). Pathomorphological peculiarities of tuberculous meningoencephalitis associated with HIV infection. Interventional Medicine \& Applied Science, 9(3), 144-149. https://doi.org/10.1556/1646.9.2017.31

[10] Kuzmina, I., Hubina-Vakulik, G., \& Burton, G. (2005). Placental morphometry and Doppler flow velocimetry in cases of chronic human fetal hypoxia. European Journal of Obstetrics \& Gynecology and Reproductive Biology, 120(2), 139-145. https://doi.org/10.1016/j.ejogrb.2004.09.001

[11] Ludwicki, J., Góralczyk, K., Struciński, P., Wojtyniak, B., Rabczenko, D., Toft, G. \& Jens Peter Bonde. (2015). Hazard quotient profiles used as a risk assessment tool for PFOS and PFOA serum levels in three distinctive European populations. Environment International, 74, 112-118. https://doi.org/10.1016/ j.envint.2014.10.001

[12] Lyngsø, J., Ramlau-Hansen, C., Høyer, B., Støvring, H., Bonde, J., Jönsson, B. ... Toft, G. (2013). Menstrual cycle characteristics in fertile women from Greenland, Poland and Ukraine exposed to perfluorinated chemicals: a cross-sectional study. Human Reproduction, 29(2), 359-367.

[13] Lytvynenko, M., Bocharova, T., Zhelezniakova, N., Narbutova, T., \& Gargin, V. (2017). Cervical transformation in alcohol abuse patients. Georgian Medical News, (271), 12-17.

[14] Lytvynenko, M., Shkolnikov, V., Bocharova, T., Sychova, L., \& Gargin, V. (2017). Peculiarities of proliferative activity of cervical squamous cancer in hiv infection. Georgian Medical News, (270), 10-15.
[15] Mor, G. (2013). The female reproductive tract and HIV: biological, social and epidemiological aspects. American Journal of Reproductive Immunology, 69, (1), 1. https://doi.org/10.1111/ aji.12082

[16] Reekie, J., Kowalska, J., Karpov, I., Rockstroh, J., Karlsson, A., Rakhmanova, A. ... Mocroft, A. (2012). Regional Differences in AIDS and Non-AIDS Related Mortality in HIVPositive Individuals across Europe and Argentina: The EuroSIDA Study. Plos ONE, 7(7). https://doi.org/10.1371/ journal.pone.0041673

[17] Rehm, J., Probst, C., Shield, K. D., \& Shuper, P. A. (2017). Does alcohol use have a causal effect on HIV incidence and disease progression? A review of the literature and a modeling strategy for quantifying the effect. Population Health Metrics, 15(1), 4. https://doi.org/10.1186/s12963-017-0121-9

[18] Roan, N. R., \& Jakobsen, M. R. (2016). Friend or Foe: Innate Sensing of HIV in the Female Reproductive Tract. Current HIV/AIDS Reports, 13(1), 53-63. https://doi.org/10.1007/ s11904-016-0305-0

[19] Scheck, S. M., Lepine, S. J., Yu, H., Robb, O., Fitzgerald, P., Clentworth, H., Maharaj, D., Tully, L., \& Tristram, A. (2020). Cytopathological review of cervical pathology: Impact for women and follow-up results. The Australian \& New Zealand Journal of Obstetrics \& Gynaecology, 60(3), 444-448. https:/ /doi.org/10.1111/ajo.13136

[20] Shepherd, L., Borges, Á., Ledergerber, B., Domingo, P., Castagna, A., Rockstroh, J. ... Mocroft, A. (2016). Infectionrelated and -unrelated malignancies, HIV and the aging population. HIV Medicine, 17(8), 590-600. https://doi.org/ 10.1111/hiv. 12359

[21] Wahlstrom, J. T., \& Dobs, A. S. (2000). Acute and long-term effects of AIDS and injection drug use on gonadal function. Journal of Acquired Immune Deficiency Syndromes, 25, 1, S27-S36. https://doi.org/10.1097/00042560-200010001-00005

[22] Zoufaly, A., Cozzi-Lepri, A., Reekie, J., Kirk, O., Lundgren, J., Reiss, P. ... Van Lunzen, J. (2014). Immuno-Virological Discordance and the Risk of Non-AIDS and AIDS Events in a Large Observational Cohort of HIV-Patients in Europe. Plos ONE, 9(1), e87160. https://doi.org/10.1371/ journal.pone.0087160

\section{МОРФОМЕТРІЧНІ ОСОБЛИВОСТІ ШИЙКИ МАТКИ ПРИ ІМУНОДЕФІЦИТНИХ СТАНАХ \\ Литвиненко М.В., Гаргін В.В.}

Посилюючи ефекти один одного ВІЛ-інфікування та зміни, зумовлені зловживанням алкоголю, запускають ланцюжок патологічних реакцій, котрі призводять іноді до зворотних, а часто і незворотніх патологічних процесів у иийці матки (ШМ). Локальне та загальне зниження імунорезистентності незмінно веде до порушення фрізіологічного мікробіому ШМ. 3 огляду на все викладене вище, метою нашої роботи стало виявлення патологічних змін ШМ, що виникають у ВІЛ-інфікованих жінок на тлі хронічного алкоголізму. Досліджено секційний матеріал 110 жінок репродуктивного віку від 20 до 40 років, які були розділені на чотири групи. Після виготовлення мікропрепаратів проводили морфометричне дослідження. Виявлено виражені патологічні зміни в ШМ у ВІЛ-інфікованих жінок, що страждали алкоголізмом. Максимальна товщина багатошарового плоского

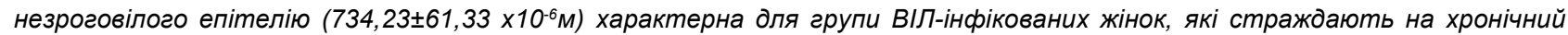
алкоголізм. У ВІЛ-інфікованих жінок цей показник на 3,14\% менше і становить 711,21士59,28 х10-6 м. У жінок, які страждають на

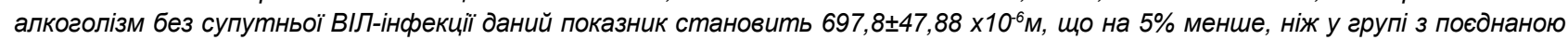

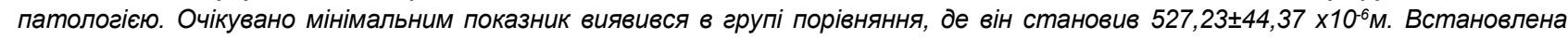
достовірна різниця між групою порівняння ВІЛ-інфрікованих жінок, що страждали алкоголізмом, і контрольною групою, яка становить 28,2\%. У досліджуваному матеріалі ВІЛ-інфікованих пацієнток визначений високий ступінь розподілу вираженості дисплазії шийки матки - 9,1\%. Помірний і низький ступінь відповідно 19,42 і 37,12\% у даній групі досліджуваних. При вивченні ступеня інфрільтрації власної пластинки слизової у групах дослідження виявлено, що найбільша кількість випадків вираженої інфільтрації (44,5\%) виявлена в групі, що страждали на хронічний алкоголізм, а в групах з ВІЛ не було виявлено жодного такого випадку. На основі проведеного дослідження можна припустити поєднаний вплив фракторів, що сприяють розвитку патологічних процесів як в епітелії, так і в слизовій оболонці ШМ. Таким чином, ВІЛ-інфрікування та зловживання алкоголем можуть посилювати патологічні ефекти один одного і призводити до виражених патоморфологічних змін ШМ, а саме: 
потовщення епітелію слизової оболонки за рахунок частого розвитку різних видів кондилом, дисплазії слизової оболонки $і$ навіть вираженої клітинної інфрільтрації власної пластинки слизової оболонки.

Ключові слова: шийка матки, ВІЛ, алкоголізм, епітелій, гістологія.

\section{МОРФОМЕТРИЧЕСКИЕ ОСОБЕННОСТИ ШЕЙКИ МАТКИ ПРИ ИММУНОДЕФИЦИТНЫХ СОСТОЯНИЯХ}

\section{Литвиненко М.В., Гаргин В.В.}

Усиливая эффректы друг друга ВИЧ-инфицирование и изменения, обусловленные злоупотреблением алкоголя, запускают цепочку патологических реакций, приводящих иногда к обратимым, а часто и к необратимым патологическим процессам в шейке матки (ШМ). Локальное и общее снижение иммунорезистентности неизменно ведет к нарушению фризиологического микробиома ШМ. Учитывая все изложенное выше, целью нашей работы было выявление патологических изменений шм, возникающих у ВИЧ-инфицированных женщин на фоне хронического алкоголизма. Исследован секционный материал 110 женщин репродуктивного возраста от 20 до 40 лет, которые были разделены на четыре группы. После изготовления микропрепаратов проводили морфометрическое исследование. Выявлены выраженные патологические изменения в ШМ у ВИЧ-инфицированных женщин, страдавших алкоголизмом. Максимальная толщина многослойного плоского неороговевающего эпителия $\left(734,23 \pm 61,33 \times 10^{-6} \mathrm{M}\right)$ была характерна для группы ВИЧ-инфрицированных женщин, страдающих хроническим алкоголизмом. У ВИЧ-инфрицированных женщин этот показатель на 3,14\% меньще и составляет 711,21士59,28 х10-6 . У женщин, которые страдают алкоголизмом без сопутствующей ВИЧ-инфекции, данный показатель составляет $697,8 \pm 47,88 \times 10^{-6} \mathrm{M}$, что на 5\% меньше, чем в группе с сочетанной патологией. Ожидаемо минимальным показатель оказался

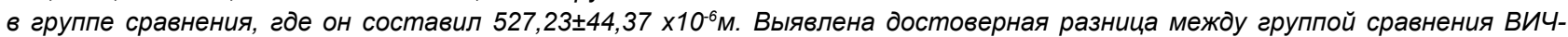
инсрицированных женщин, страдавших алкоголизмом, и контрольной группой, которая составляет 28,2\%. В исследуемом материале ВИЧ-инфицированных пациенток определена высокая степень распределения выраженности дисплазии шейки матки - 9,1\%. Умеренная и низкая степень соответственно 19,42 и 37,12\% в данной группе исследуемых. При изучении степени инфильтрации собственной пластинки слизистой в группах исследования выявлено, что наибольшее количество случаев выраженной инфильтрации (44,5\%) выявлено в группе с хроническим алкоголизмом, а в группах с ВИЧ не было выявлено ни одного такого случая. На основе проведенного исследования можно предположить сочетанное влияние фракторов, способствующих развитию патологических процессов как в эпителии, так и в слизистой оболочке шм. Таким образом, ВИЧ-инфекция и злоупотребление алкоголем могут усиливать патологические эфффекты друг друга и приводить к выраженным патоморфологическим изменениям ШМ, а именно: утолщению эпителия слизистой оболочки за счет частого развития различных видов кондилом, дисплазии слизистой оболочки и даже выраженной клеточной инфильтрации собственной пластинки слизистой оболочки.

Ключевые слова: шейка матки, ВИЧ, алкоголизм, эпителий, гистология. 